\title{
The End of the Wooden Shop: Whanganui architecture in the 1890s
}

Wendy Pettigrew, independent researcher, \& Mark Southcombe, School of Architecture, Victoria University, Wellington

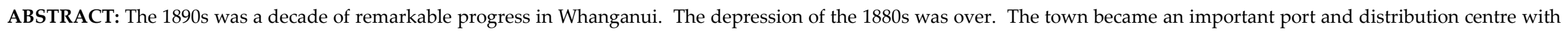

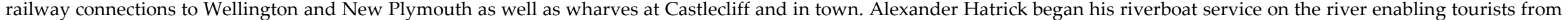

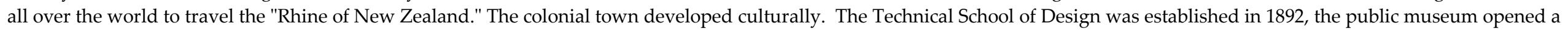

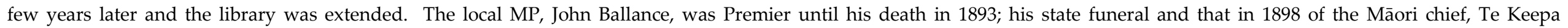
Rangihiwinui, were defining moments in Whanganui's history.

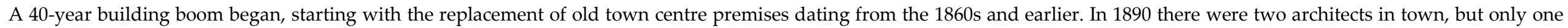

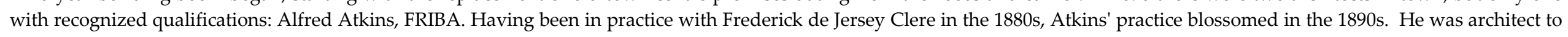

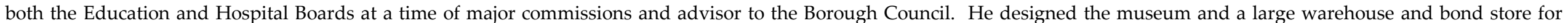

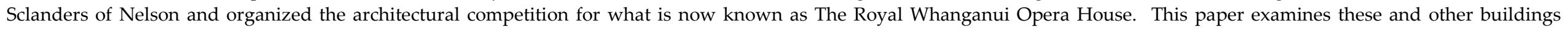
together with some "gentlemen's residences" as examples of the Victorian architecture which characterizes Whanganui today.

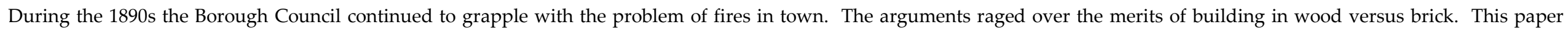

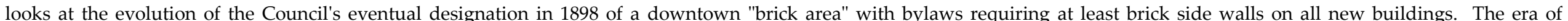

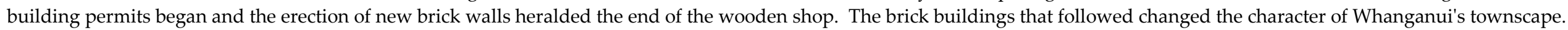

The 1880s had been a busy decade for Whanganui, with the Borough Council undertaking major infrastructure works including riverside reclamation schemes that resulted in the construction of a town wharf and more building sites. Taupo Quay was no longer "the beach." The last physical reminder of Whanganui's days as a garrison town, the old Rutland Stockade, was demolished in 1883 having served as the town goal following the departure of the imperial regiments. The depression of the 1880s that affected all of New Zealand had left its mark with even the past mayor, and well-known merchant,
William Hogg Watt, declared bankrupt in 1887.1 By the beginning of the 1890s, however, Whanganui was in a position to capitalize on its new communication links with new port facilities and the completion of the railway to Wellington. New industries were being established including the Wanganui Meat Freezing Works at Castlecliff which was a catalyst for the growth of this seaside suburb from 1891 onwards. The construction industry elsewhere in New Zealand was still in the doldrums in the early

${ }^{1}$ Watt Biographical Notes on William Hogg Watt p 7.
$1890 \mathrm{~s},{ }^{2}$ but in Whanganui it was a different matter. The town was growing rapidly. Its population increased by a third between 1890 and 1895, creating a demand for more housing, bigger business premises and other facilities such as schools, hotels and a new hospital. ${ }^{3}$ The opportunity to further develop the Whanganui River as a "highway" to the interior of the North Island was grasped by local entrepreneur, Alexander Hatrick. He obtained government support for a river boat

${ }^{2}$ New Zealand Official Year Book 1937 p 447.

3 "Population of Wanganui-Borough and Suburbs" p 2. 
service which started with the maiden voyage of the Wairere in December 1891. Hatrick's river services increased throughout the 1890s as Whanganui became a popular tourist destination, with people coming from all over the world to travel "the Rhine of New Zealand." Mark Twain was one of the more celebrated visitors to visit the town; he expressed his horror about the inclusion of the words "fanaticism" and "barbarism" on the 1865 Moutoa war memorial when he visited in December 1895 to lecture at the Oddfellows Hall. $^{4}$

Whanganui was becoming more culturally sophisticated even before the tourists arrived. Existing theatrical entertainments were well patronized, often taking place in the Oddfellows Hall for lack of any other public theatre. The public library established in 1874 was now located in a building erected in 1882 with additions from 1898 onwards. The building is still standing today as the Repertory Theatre. A local jeweler, Samuel Drew, had his own private museum with a large natural history collection housed above his shop. Discussions started in 1892 about developing this as a public museum in its own

${ }^{4}$ Maclean \& Phillips The Sorrow and the Pride p 24. building. At the centre of these discussions was one of the local architects, Alfred Atkins, who was involved in numerous community activities.

Atkins had started his architectural practice in Whanganui in 1880 after working in New Zealand as a railway engineer for five years. He was the son of a solicitor, educated in Birmingham first at King Edward's Grammar School, by then housed in Charles Barry's 1835 Gothic edifice in New Street, and then at the School of Design where he studied building construction and architectural drawing. From 1867 to 1875 he trained and worked with the engineer John Millward and spent time travelling around England on inspection tours when he "missed no opportunity of visiting and making sketches of buildings of interest."5 Atkins purchased the Whanganui architectural practice of Walter Cole in $1880 .{ }^{6}$ By February 1883 when he went into partnership with Frederick de Jersey Clere he had already designed a range of buildings including 17 houses, two of which were large two-storey dwellings for prominent Whanganui citizens. Atkins \& Clere were

${ }^{5}$ Atkins Nomination Papers.

6 "Notice: Mr Walter Cole ... [re: A. Atkins]" p 17. appointed joint architects to the Wanganui Education Board, a position Atkins retained until 1902. They worked together on a variety of other commissions, including Overton, the 20-room country house built for Francis Arkwright north of Marton. The time spent working alongside Clere would have influenced Atkins' work, especially the small churches he was to design in the following 20 years. In particular, Atkins' design for the 1892 chancel extension to St Mary's at Ūpokongaro, his delightful 1902 Batley Memorial Chapel at Moawhango and his 1908 church at Matarawa all have some similarities with Clere's designs for churches and their furniture. Shortly after their partnership was dissolved in February 1888, Clere proposed Atkins for membership as a Fellow of the Royal Institute of British Architects. The two men kept in touch after Clere set up his own practice in Wellington; Clere passed work on to Atkins ${ }^{7}$ and provided support during the tendering process for the new hospital in Whanganui. ${ }^{8}$

One of Atkins' major commissions in the 1890s was the design of the new Wanganui

\footnotetext{
${ }^{7}$ Pettigrew, The Church by the River p 13.

8 "Tenders [Notice for Wanganui Hospital]" p 3.
} 
Girls' College, completed in time for the start of the school year in 1891. This large, wooden two-storey building was set in landscaped grounds in Liverpool Street near the site where the new Collegiate School would be built in 1910. The Wanganui Herald described the girls' college as "a building that at once arrests the eye of the visitor, not only for its commanding aspect but also for the neatness and general excellence of design in the architecture." 9 The sanitary arrangements of the drains were praised, as well as the provisions against fire - sprinklers over each staircase, doors opening outwards and straight staircases. It never did burn down and was demolished after the school boarders moved out in 1976 to make way for the community polytechnic. The Minister for Education, William Pember Reeves, opened the college on 12 February 1891 with the new Premier and local MP, John Ballance, also on the platform. Reeves commented that he had read a description of the school which "described the architecture as simple, but effective and of Swiss character" but he thought this "a press euphonism suitable for an oblong box."10

\footnotetext{
9 "Wanganui Girls' College: Description of the New Building" p 1.

10 "Wanganui Girls' College: Formal opening ceremony"
}

The following September the Technical School of Design opened with David Blair as "art master" and principal. Only the third such school in New Zealand at the time, the School of Design opened in small premises designed by Alfred Atkins in his role as Education Board architect. Blair had been the first director of the Canterbury College School of Art in 1881 and turned down an offer of a post at Ballarat to set up the school in Whanganui. ${ }^{11}$ As well as art classes and subjects meeting the South Kensington examinations curriculum, Blair offered instruction at evening classes in engineering and architecture. These classes went well for a few years, but by the end of 1894 Blair proposed discontinuing the architecture classes because of inadequate facilities and lack of teaching support. Blair commented to the Wanganui Education Board in his report for 1894 that architecture lectures "including plane and solid geometry, are much more instructive and interesting than simply copying drawings from flat examples, of which the student soon tires." ${ }^{12} \mathrm{He}$ considered it impossible to prepare for subjects like engineering and architecture

p 2.

11 "The Technical School of Design" p 7.

12 "Art Master's Report" E1, p 65. under three or four hours. Teaching assistance must have been forthcoming because the engineering and architecture students at the school in 1895 exhibited 16 drawings at the student exhibition held in February 1896. ${ }^{13}$ Architecture classes were again in doubt in 1896 when Theo Jacobsen, an architect from Wellington who practised in Whanganui for a couple of years, decided to start his own evening classes so that "mechanics" as well as boys (who might otherwise be "wasting their time on the streets") might "learn the valuable profession of architecture."14

Jacobsen had very definite views on the value of training for an architect and was upset when the Oddfellows chose local builder, Tommy Johns, to design their new hall in Ridgway Street. In a letter to the newspaper, Jacobsen commented "Is it fair to us, who had to be articled for five years in order to qualify us as architects, that a builder should be selected in preference to us?"15 Johns was a Lodge member and offered to plan the hall for no fee. He later moved to Wellington and was one of those who first registered as an

\footnotetext{
13 "Technical School exhibition of students' work" p 2.

14 "The question has always arisen ... [Local and General News]" p 2, column 6."Public Notices" p 3, column 3.
} 15 "The Oddfellows' Lodge Room" p 16 
architect in 1914. His son, Bernard Johns, also became an architect whose work merited NZIA awards. Jacobsen was in Whanganui long enough to design the new Provincial and Metropolitan Hotels built in 1896, the latter retaining many of its architectural features despite losing part of its upper storey in a fire in 1949. The other prominent architect in Whanganui during the 1890s was William Pinches who was well-known locally for his choir singing. In 1893 Pinches was commissioned by a wealthy new settler, George Palmer, to design what was the largest house in Whanganui at the time - a 26-room plus attics two-storey residence at Westmere. Known as Woodlands, only faint photographs exist of this house which was demolished in 1942 when its totara and kauri timber was reused to build a new single-storey bungalow.

During the early 1890s the plans for the public museum progressed. By 1893 Atkins had persuaded the committee that it would not be appropriate to add another storey to the library building. He considered a "perfectly plain building of smaller size might possibly be erected for $£ 200 . " 16 \quad$ Located in Queen's Park on a site leveled by local prisoners, the

\footnotetext{
16 "At a meeting of the Museum Committee" p 2.
}

building was completed at the end of 1893 although not formally opened to the public for some time afterwards. The initial building for the museum was small. It was designed to have "the largest amount of accommodation possible for the money to be expended" so its appearance was "necessarily plain on the outside, the walls being covered with corrugated iron (for increased safety from fire) relieved by timber facings and other woodwork about the gables."17 The interior was lit by skylights above the coved ceiling and the walls were matchlined with oiled timber. The building was accessed by steps from the street that was later named Drews Avenue. In 1899 a lecture hall was added to the museum. A second museum was built in 1928 elsewhere in Queen's Park on a site chosen by Samuel Hurst Seager in his 1926 plans for Wanganui's Civic Centre. The Wanganui Savage Club moved into the original museum building in 1931 and remains there today. "Savage Clubs" originated with an 1857 London gentlemen's club and local clubs were established in New Zealand from the 1880s. They provide charity variety concerts, often with a Māori flavour.

\footnotetext{
17 "Wanganui Public Museum" p 15.
}

The building boom in Whanganui continued unabated throughout the mid 1890s. Many of the original timber buildings erected in the 1860s and 1870s had reached the end of their useful life. There was also the issue of leasehold land requirements. The painting and decorating firm, Tingey's, had to rebuild their Victoria Avenue shop in 1896 because their 1872 lease with the Taylor Estate required them to renew the building within 25 years. ${ }^{18}$ Wooden buildings were not considered to be permanent - many of those who commissioned buildings in the 1890s would be surprised to see what is still standing today. Two Westport contractors, Robert Russell and Arthur Bignell moved to Whanganui in 1893 and joined the existing group of builders in town which included Nicholas Meuli, John Randal and Thomas Battle. As well as working with the local architects, these men designed many of the houses they built for local clients as demand for housing grew throughout the borough and adjoining suburbs. Many of these new houses incorporated doors, sashes, mouldings and fireplaces made by the Wanganui Sash \& Door Company, a large Whanganui enterprise that supplied crafted building elements for

18 "Business Improvements" p 2. 
construction throughout the lower North Island and beyond.

As early as 1877 the term "villa" was being used to describe some new houses in Whanganui. A number of "villas" were built in the 1880s but the design of villa residences developed further during the 1890s. Some notable houses from the period included Bignell's own house in Heads Road and his hillside villas built for Richard Baddeley and John Duncan (the latter now moved elsewhere). One of the most imposing is the Riverlands residence built in 1893 for Joseph Paul, a draper from Somerset. Paul proudly claimed to have altered a building in Victoria Avenue to house his drapery store without the benefit of an architect. ${ }^{19}$ It is likely therefore that he and his builder, John Randal, designed Riverlands as no relevant architect's tender notice has yet been located. This large family home has an extremely wide hall at both ground and first floors which is used for indoor games by the young children who live there today.

The construction of new warehouses was a major development in town as merchants took

${ }^{19}$ Cyclopedia of New Zealand v II, p 1415. advantage of Whanganui's port and railway distribution network. The long-established Nelson firm of James Sclanders opened a Whanganui branch in 1885, taking over the Taupo Quay premises rebuilt for Taylor \& Watt in the 1860s. By the early 1890s, Sclanders \& Co was in a position to rebuild on the site and engaged Alfred Atkins to design a new warehouse and bond store which the local newspaper described as "a pile of buildings which will be second to none in town."20 The warehouse site already fitted the government's requirements that bond stores should be located no more than 1,000 yards from the Custom House with a street entrance "to allow customs officers to have access to the Crown's lock at all hours."21

To assist Atkins with his plans, Thomas Young, the Whanganui manager for Sclanders \& Co, sought advice from Mr Martin of James Goss' Canterbury Steam Saw Mills in Christchurch as to the requirements for the foundations of the new warehouse. Martin responded in April 1894 with a sketch and specifications for the concrete foundations, designed to carry the weight of the goods and

\footnotetext{
20 "The Week: Saturday" p 5, column 4.

21 Information here and in paragraph below from
} Sclanders \& Co. Records. also to ensure that no vermin could ever gain access to the building. He also suggested that tōtara would be the best timber for plates, sleepers and joists; red pine (rimu) for the floors and that the doors be made with Baltic frames and covered with either red pine or kauri. Atkins appears to have followed the advice from Martin and was under strict instructions from Sclanders to design an economical but "best quality" warehouse. The two-storey building was planned to have the bond store and grocery, flour and produce stores on the ground floor with light merchandise and drapery goods upstairs. Atkins estimated it would cost $£ 2,400$. James Sclanders considered this "more costly than need be" although he acknowledged that the building would need to be strong enough to hold a considerable weight with the goods stored therein. A four-page list of recommended alterations was sent up to Whanganui in May 1894. Most of these were accepted by Thomas Young but he wrote back to Sclanders that "in a few cases I most certainly protest." The recommendations had extensive comments about flattened versus ground glass in the drapery warehouse lantern lights and other locations. Sclanders did not want the interior of the drapery room to be painted. "I most decidedly disagree with 
you on this point" commented Young. "A large square room such as our drapery department will be, would look like a huge barn unless it were nicely painted. ... I know from experience that a room nicely painted in a pale shade (say French grey) is a very great help in showing off the stock to best advantage." Young also held out for gold lettering for the firm's name on the upper pediment as this "would add very considerably to the appearance of the building and as the extra cost is trifling I do not consider it wise to alter it."

The eventual cost was $£ 2,220$, the lowest tender received from Russell \& Bignell. Seeing the foundations being laid in August 1894, the Wanganui Herald sent a reporter to visit Atkins in his office. The reporter commented that Atkins was "very kind" in showing him the plans for the "massive building" shortly to be erected. ${ }^{22}$ The construction required more than 200 cubic yards of concrete for the foundations with 100,000 feet of timber, all heart tōtara, matāi and rimu. The outside walls, except the front, were to be covered with corrugated iron with water sprinklers around the eaves. The front

22 "Business Improvements in Town" p 16. elevation was considered to "present an imposing appearance" with the finishing throughout of the "very best character." With more than 13,000 feet of floor capacity, it was to be the largest warehouse in the district. By early 1895 the warehouse was completed, including its interior fittings. In 1901 Levin \& Co bought out Sclanders \& Co and remained in the warehouse until 1926 when they moved to a new reinforced concrete building further along Taupo Quay.

Atkins designed a number of other commercial buildings along Taupo Quay in the 1890s, including the warehouse for Thain's (now housing offices and an apartment) and new offices for the Wanganui Chronicle newspaper, the façade of which was modernised in 1954. Another architect acquaintance of Atkins, Thomas Harvey James, returned to Whanganui in 1897. Educated at Collegiate School, James was the first New Zealand-born architect to practise in Whanganui. He trained under Frederick de Jersey Clere and practised in Feilding and Palmerston North in the 1890s. His first office in Whanganui was in Cummins' building in Ridgway Street in rooms which would accommodate another architectural practice 90 years later. One of James' first commissions was the design of a new boat shed for the Wanganui Rowing Club, completed in 1898 and built by Nicholas Meuli. Originally just a single-storey building, the second storey was added in 1905 presumably to James' design as he was a Club official and their honorary architect. In the late 1890s, James designed a number of houses, including a two-storey villa in the Turakina Valley for James Bowen which is known as Pembroke Vale. He was also likely to have designed a Whanganui riverside villa for the Notman family, built in 1899 by William Knuckey.

By the 1890s Whanganui's sophistication and status as a major provincial centre was growing. John Ballance had been responsible for increasing the interest in his home town while Premier. His untimely death in 1893 was followed by a state funeral with special trains laid on to bring mourners from Wellington. His widow travelled to England shortly afterwards and commissioned his granite memorial which was erected at Heads Road Cemetery in February 1895. Ballance's other Whanganui memorial, a statue, was subscribed to by local people and first erected in Queen's Park in 1898 before being moved to Moutoa Gardens. For nearly 100 years, Ballance's statue stood close to the even more 
impressive statue of Te Keepa Te Rangihiwinui (Major Kemp), the Māori chief who had supported the government during the New Zealand Wars and was highly respected within Maoridom as well as by Pākehā. Kemp's state funeral in 1898 was as impressive as that of Ballance. Government representatives stood alongside local Māori and special trains brought mourners from all over New Zealand for his burial at Pūtiki. The Wanganui Herald noted "Seldom if ever in the history of this colony has a Maori chief or warrior been honoured with a larger or more representative funeral."23 Kemp's statue at Moutoa was commissioned by his sister in 1913. Ballance's statue was destroyed in the 1995 occupation of Moutoa Gardens although the plinth and its inscription remain. A new statue is now being commissioned for erection at a less sensitive location in Whanganui.

As the 1890s drew to a close, Whanganui was lacking one vital community asset - a good theatre. Queen Victoria's Jubilee in 1897 provided the stimulus for the establishment of the Wanganui Opera House Company to raise the necessary capital to build a municipal

\footnotetext{
23 "The Late Major Kemp" p 2.
}

theatre. ${ }^{24}$ As expected, there were arguments as to the best site - reserve land being much the cheaper option for the Borough Council. Eventually the site in St Hill Street next to the (then) Council Chambers was chosen and Alfred Atkins was asked to plan an architectural competition for designs for the opera house. The competition was advertised nationally with nine entries being received for assessment by two retired builders in Wellington, Thomas Scoular and James Barry. The winner was George Stevenson from Wellington, with two other Wellington architects, William Crichton and Joshua Charlesworth, placed second and third respectively.

George Cron Stevenson was born in Belfast and worked as an engineer/architect with the government in New South Wales ${ }^{25}$ before coming to New Zealand, where he was married in 1889 . He continued to work as an architect with the Public Works Department in Wellington until establishing his own practice there in August 1898. ${ }^{26}$ Further research into Stevenson's career, including his work in the Public Works Department, may

${ }^{24}$ Robinson A Grand Victorian Lady pp 12-31.

25 "Local and General [News]" p 4.

26 "Geo. C. Stevenson, Architect" p 1, column 5. shed more light on this architect and his work. His detailed plans for the Opera House indicate that he had considerable skills as an architect and draughtsman; he would have gained this experience while working with John Campbell in the Public Works Department. The Opera House appears to have been Stevenson's major project while in private practice as he had very few published tender notices in the Evening Post for work apart from alterations to houses. The terms of the Opera House competition were that the winner would supervise the construction and receive $5 \%$ commission on the total cost. The Borough Council wanted to keep the construction cost below $£ 3,800$ and reserved the right to disqualify the winning architect should the tenders come in above this amount, which they did as $£ 4,597$ was the lowest tender. The Mayor, Alexander Hatrick, gained the support of both Crichton and Charlesworth that Stevenson should not be disqualified. However, Stevenson became ill in 1899 and was not able to supervise the job so agreed to accept a lump sum of 55 guineas for his plans and specifications and forego his commission (which would have been some £200). A local builder, James Tawse, was appointed to supervise Nicholas Meuli's firm in constructing the theatre. Stevenson 
subsequently died on 26 June 1899 aged 42 years so never saw the completion of his Opera House. ${ }^{27}$

The foundation stone was laid with great pomp and ceremony on 13 July 1899 . It was a remarkable construction job even by today's standards, being a two-storey timber building with an extensive cellar, fly tower and upper roof area. A steam crane would have been needed to lift the huge timber beams used for the roof supports. The fact that the theatre was completed in time for its official opening on 9 February 1900 was equally remarkable, although the detailed plans provided by Stevenson would have been of great assistance to the builders. Premier Richard Seddon noted in his address at the opening that the Borough Council "was the first municipal body south of the equator" to have developed a public theatre. ${ }^{28}$ It was also the first theatre in New Zealand to have electric lights although these proved rather expensive to run until the borough tramway system was set up in 1908.

\footnotetext{
27 "Deaths: Stevenson" p 6.

${ }^{28}$ Robinson A Grand Victorian Lady p 31.
}

The front elevation of the theatre as built differed slightly from Stevenson's design, which was carefully planned to complement the Council Chambers next door. The main entrance to the Dress Circle was moved to the centre of the building with balustraded porticos above all doorways. The central portico was changed later (probably in 1919/20 to designs by Henry Monk Helm) to provide the covered entrance still in place today. At the same time, the entrances to the stalls and the pit were altered. Interior alterations have also taken place over the years, but the auditorium retains its original design with cast iron railings delineating the dress circle and a cast iron ventilation grill in the centre of the dome. The seats are also original, but their layout has changed on more than one occasion. The building has had several major additions to the side and rear to accommodate scenery and the needs of theatrical companies - and from 1920 until the 1940s the Opera House was also a movie theatre. It is still in constant use, hosting theatrical events, concerts, ballet and fashion shows. To mark the centenary of this remarkable Victorian theatre, it received a Royal charter and is now the Royal Wanganui Opera House.

\section{Building Regulations}

Whanganui had a voluntary fire brigade in action from 1868, but even prompt action by firefighters was not sufficient to stop the frequent destruction by fire of wooden buildings in town. There were a number of serious fires in the centre of Whanganui in the mid-1890s. Five shops in Victoria Avenue, including Hannah's Boot and Shoe store, were destroyed in $1894^{29}$ followed in May 1896 by a Ridgway Street fire that burnt down Cummins' shop and the office building occupied by local solicitor, Cornelius Burnett. Wanganui Borough Councillors were particularly concerned when most of the business centre of Hāwera in South Taranaki was destroyed by fire in August 1895. ${ }^{30}$ They did not want this to happen in Whanganui and by October 1895 were planning to designate part of town centre as a "brick area" with by-laws requiring all new buildings to have brick side walls as a minimum requirement.

Whanganui was late in reaching such a decision. The City of Auckland Building Act had prohibited wooden construction in the

\footnotetext{
29 "A Disastrous Fire" p 2.

${ }^{30}$ Bromley Hawera District Centenary p 88.
} 
centre of town from 1856 while Timaru drew up by-laws requiring new commercial buildings to be constructed of brick or stone in December 1868 following a disastrous town centre fire. ${ }^{31}$ Discussions had been under way in Whanganui about the merits of building in wood versus brick as early as 1893 when plans were being drawn up for a new hospital. The Wanganui Herald in its editorial on 7 September 1893 commented that "Preference should be given to something that will last and not be liable to destruction by fire." Wood, although cheaper than brick or concrete, was also likely to "become saturated with the germs of disease" 32 which was clearly a concern for the hospital design. The first Whanganui Hospital, constructed in 1848, was originally planned as a brick building but the specifications were changed to timber following a serious earthquake in Wellington. ${ }^{33}$ Alfred Atkins was at the centre of discussions in 1893 about the new hospital, assisting in the decision about the site as well as materials. Atkins' opinion that brick was preferable for the hospital was shared by Dr Robert Earle who still had concerns about

\footnotetext{
${ }^{31}$ McLean New Zealand Tragedies pp 37-38.

32 "The New Hospital" p 2.

33 "Colonial Hospital Wanganui [Tender Notice]" p 2; "Native Hospital Wanganui [Tender Notice]" p 2.
}

earthquakes. Atkins' views were reported that "it was almost impossible to get a brick face to remain without injury after a certain time. Double walls would be good, but expensive - make the building waterproof with bricks and cement facing, and on the inside he could see of no better way than plastering and painting it." 34 The decision was taken to build the hospital in brick, no doubt assisted by the government's decision to provide a grant only if brick was the main construction material. Designed by Atkins and built by Russell \& Bignell between 1894 and 1897, the Wanganui hospital was the first building of any magnitude built of brick on the west coast of the North Island. ${ }^{35}$ It was opened with due ceremony on 12 March 1897 by Premier Richard Seddon who was clearly so impressed by Atkins' design that he recommended him for the new Greymouth hospital. The Wanganui hospital was designed with a number of linked pavilions containing the wards, each with an open verandah at one end, on either side of the twostorey central administration block. The design was also used for the Hamilton hospital constructed by Russell \& Bignell in

\footnotetext{
34 "Wanganui Hospital Board" p 2.

${ }^{35}$ Wright St-Clair Caring for People p 22.
}

1906/1907 and Atkins later designed hospital buildings for Wellington, South Wairarapa, Gisborne and New Plymouth.

The decision to build the hospital in brick passed the test in December 1897 when a serious earthquake caused much damage in Whanganui but none to the hospital. At the time there were two other privately-owned brick buildings in town (location not known) which also escaped damage. A brick party wall built in 1895 for furnisher, John Anderson "came to grief" in the earthquake, as predicted "by those in the know" according to the Wanganui Herald. ${ }^{36}$ Clearly this was a reflection on the quality of the design and construction of the masonry work. Atkins had been involved in drawing up the specifications for the borough's building regulations and defining the inner area of town which would require new buildings to have brick dividing walls no less than 13 inches thick (for two-storey buildings) or $17 \frac{1}{2}$ inches for three-storey buildings. ${ }^{37}$ Although first published in October 1896, the proposed building regulations took some time to be considered by borough councillors who had

\footnotetext{
36 "Earthquake Reports" p 2.

37 "The Borough Building Regulations" p 2.
} 
concerns about adopting such a report "at a moment's notice."38 There was general support, however. As well as requiring brick party walls (wooden front and rear elevations were still allowed), building permits would be required and buildings were to be inspected while under construction. It was September 1897 before the Council formally adopted the new regulations, which came into effect in January 1898. The old register of building permits has entries from April 1898 with the new Ridgway Street offices for the ex-Mayor's firm, Freeman R Jackson \& Co, being one of the first to be entered with the notation "brick party walls."

The new brick walls heralded the end of the wooden shop in Whanganui and contributed to a major change in the character of the townscape. A large number of brick buildings, many with ornate façades, were constructed in town in the period up to the Great War. Some of these are now themselves at risk, requiring earthquake strengthening if they are to continue to feature in the townscape. The main rationale for the brick party walls, to stop the spread of fire, was also tested and found lacking on a number of occasions. A major 1987 fire in Victoria Avenue resulted in the demolition of a number of 1913 brick buildings. Cummins' building erected with brick party walls in 1896 after one disastrous fire was destroyed by an even more destructive fire in 1994.

\footnotetext{
38 "The Borough Building Regulations" p 2.
} 


\section{REFERENCES}

"A Disastrous Fire - Five shops wrecked in the Avenue" Wanganui Herald (27 January 1894):2.

"Art Master's Report," Wanganui Education Board Report for 1894, Appendix E1: Education, Appendices to the Journal of the House of Representatives, 1895:65.

"At a meeting of the Museum Committee [Local \& General News]" Wanganui Herald (19 March 1892):2.

Atkins Nomination Papers, Microfiche 103/G2, Royal Institute of British Architects, London.

"The Borough Building Regulations: The Committee's Report" Wanganui Herald (14 October 1896):2.

Bromley, APC Hawera District Centenary Hawera: Centennial Committee of the Hawera District Council, 1981.

"Business Improvements in Town: Messrs Sclanders \& Co's New Warehouse" Yeoman (18 August, 1894):16.

"Business Improvements: R\&E Tingey's New Premises in Avenue" Wanganui Herald (22 April 1896):2.

"Colonial Hospital Wanganui [Tender Notice]" New Zealand Spectator and Cook's Strait Guardian (11 November 1848):2.

Cyclopedia of New Zealand Wellington: Cyclopedia Company, Ltd., 1897.

"Deaths: Stevenson" Evening Post (26 June 1899):6.

"Earthquake Reports" Wanganui Herald (8 December 1897):2.

"Geo. C. Stevenson, Architect" Evening Post (11 August 1898):1, column 5.

"The Late Major Kemp: An Impressive Funeral Ceremony" Wanganui Herald (24 April 1898):2.

"Local and General [News]" Evening Post (2 September 1898):4.

Maclean, Chris and Jock Phillips The Sorrow and the Pride Wellington: GP Books, 1990.

McLean, Gavin New Zealand Tragedies: Fires and Firefighting Wellington:
Grantham House, 1992.

"Native Hospital Wanganui [Tender Notice] New Zealand Spectator and Cook's Strait Guardian (30 September1848):2.

"The New Hospital" Wanganui Herald (7 September 1893):2.

New Zealand Official Year Book, Wellington: Government Printer, 1937.

"Notice: Mr Walter Cole ... [re: A. Atkins]" Weekly Herald (22 May 1880):17.

"The Oddfellows' Lodge Room: To the Editor" Yeoman (20 July 1895):16.

Pettigrew, Wendy The Church by the River: St Mary's Upokongaro Wanganui: Parish of Eastern Wanganui, 2005.

"Population of Wanganui-Borough and Suburbs" Wanganui Herald (28 May 1896):2.

"Public Notices" Wanganui Herald (29 June 1896):3, column 3.

"The question has always arisen ... [Local and General News]" Wanganui Herald (29 June 1896):2, column 6.

Robinson, Penny A Grand Victorian Lady: The Life and Times of the Wanganui Municipal Opera House 1899-1999 Wanganui: Friends of the Wanganui Opera House, 1999.

Sclanders \& Co Records 1845-1902, AG 118, Box 7, Nelson Provincial Museum

"Technical School exhibition of students' work" Wanganui Herald (5 February 1896):2.

"The Technical School of Design" Wanganui Technical College: Golden Jubilee 1911-1961 Wanganui: [Wanganui Technical College], 1961):7.

"Tenders [Notice for Wanganui Hospital (plans at Clere \& Richmond, Wgtn)]" Wanganui Herald (6 November 1894):3.

"The Week" Yeoman (19 May 1894):4-7.

"Wanganui Girls' College: Description of the New Building" Wanganui Herald (24 February 1891):2. 
"Wanganui Girls' College: Formal Opening Ceremony" Wanganui Chronicle (13 February 1891):2.

"Wanganui Hospital Board" Wanganui Herald (14 September 1893):2.

"Wanganui Public Museum: Description of the Building" Yeoman (20 May 1893):15.

Watt, Jim Biographical Notes on William Hogg Watt Havelock North: Jim Watt, 2007.

Wright St-Clair, R.E. Caring for People: A history of the Wanganui Hospital Board 1885-1985 Wanganui: Wanganui Hospital Board Centennial Celebrations Committee, 1987. 